\title{
Cinnamon Promotes Growth Performance, Digestive Enzyme, Blood Parameters, and Antioxidant Activity of Rainbow Trout (Oncorhynchus mykiss) in Low-Carbohydrate Diets
}

\author{
Mitra Ravardshiri ${ }^{1}$, Somayeh Bahram ${ }^{1 *}$ (D), Seyed Rohollah Javadian ${ }^{1}$ (i), Masoumeh \\ Bahrekazemi $^{1}$
}

${ }^{1}$ Islamic Azad University, Department of Fisheries, Qaemshahr Branch, Qaemshahr, Iran.

\begin{abstract}
How to cite
Ravardshiri, M., Bahram, S., Javadian, S.R., Bahrekazemi, M. (2021). Cinnamon Promotes Growth Performance, Digestive Enzyme, Blood Parameters, and Antioxidant Activity of Rainbow Trout (Oncorhynchus mykiss) in Low-Carbohydrate Diets. Turkish Journal of Fisheries and Aquatic Sciences, 21 309-322. http://doi.org/10.4194/1303-2712-v21_7_01
\end{abstract}

\section{Article History}

Received 14 December 2020

Accepted 23 March 2021

First Online 26 March 2021

\section{Corresponding Author}

Tel.: +981142155117

E-mail: bahram.somayeh123@gmail.com

\section{Keywords}

Blood performance

Dietary additives

Hematology

Immunostimulants

\begin{abstract}
This study was conducted to investigate the effect of cinnamon in high- and lowcarbohydrate diets on the physiology of rainbow trout (Oncorhynchus mykiss) $(16.12 \pm 1.33 \mathrm{~g})$. Six experimental diets including control/LCarb $(200 \mathrm{~g} / \mathrm{kg}$ carbohydrate), LCarb-3C (200 g/kg carbohydrate, $30 \mathrm{~g} / \mathrm{kg}$ cinnamon), LCarb-5C ( $200 \mathrm{~g} / \mathrm{kg}$ carbohydrate, $50 \mathrm{~g} / \mathrm{kg}$ cinnamon), HCarb (300 g/kg carbohydrate), HCarb-3C ( $300 \mathrm{~g} / \mathrm{kg}$ carbohydrate, $30 \mathrm{~g} / \mathrm{kg}$ cinnamon), and HCarb-5C ( $300 \mathrm{~g} / \mathrm{kg}$ carbohydrate, 50 $\mathrm{g} / \mathrm{kg}$ cinnamon) were formulated to feed fish for eight weeks. The results showed that fish fed dietary LCarb-3C (72.64 g) and LCarb-5C (73.17 g) had higher weight gain as compared with treatments without cinnamon $(P<0.05)$. Blood performance in LCarb$3 C(67.10)$ was significantly higher than the $\mathrm{HCarb}-3 \mathrm{C}$ group $(\mathrm{P}<0.05)$. Fish fed dietary LCarb-3C had the best performance so that cinnamon in this group lowered glucose, total cholesterol, and low-density lipoprotein, improved total protein, and highdensity lipoprotein contents. Supplementation of this herb also improved protease and lipase in LCarb-3C and LCarb-5C groups as compared with control. Individuals fed supplemented diets but not $\mathrm{HCarb}$ had a higher superoxide dismutase activity when compared with the control group $(\mathrm{P}<0.05)$. Generally, cinnamon improved parameters in this study in fish fed a low-carbohydrate diet rather than a high-carbohydrate diet.
\end{abstract}

\section{Introduction}

Providing food for humans is one of the most crucial challenges ahead for humanity. This issue has attracted the attention of nations to enhance the number of aquaculture products in their food basket. Furthermore, the high-quality proteins which come from aquaculture products have made the aquaculture industry the most ongoing section in the food industry, with $8 \%$ growth each year (FAO 2020). As the profitability of any aquaculture farm relies on growth performance and feed efficiency, any actions for improving these parameters, such as dietary manipulations, can be a crucial step toward achieving sustainability of aquaculture (Asadi et al., 2020; Asgari et al., 2020; Ghosi Mobaraki et al., 2020). Supplementation diet with herbal medicine is one of these approaches because they are rich in various compounds, including phenols, tannins, alkaloids, terpenoids, and polysaccharides (Van Wyk and Wink 2018). Herbal medicine can not only promote growth performance but also can improve antioxidant capacity, 
flesh quality; and stimulate digestive enzymes, appetite, and the immune system. A long list of herbal medicines such as garlic (Allium sativum) (Esmaeili et al., 2017a; Esmaeili et al., 2017b), barberry (Berberis vulgaris) (Ramezanzadeh et al., 2020a; Ramezanzadeh et al., 2020b), dill (Anethum graveolens) (Zeilab Sendijani et al., 2020), and spotted lady's thumb (Polygonum minus) (Adel et al., 2020) and others (Citarasu 2010; Elumalai et al., 2020) have been formulated to the rainbow trout (Oncorhynchus mykiss) diets to improve the growth.

One of the most popular medicinal herbs is cinnamon (Cinnamomum verum), which has been consumed for thousands of years. The main chemical constituents of cinnamon are cinnamaldehyde, cinnamyl alcohol, cinnamic acid, and coumarin (He et al., 2005). Research in humans and animals showed this herb has many features such as antioxidant, antiinflammatory, antidiabetic, antimicrobial, anticancer, hypoglycemic effect, and lipid-lowering effect (Goel and Mishra 2020; Pandey et al., 2020; Sierra-Puente et al., 2020). Researchers observed these effects in chicken (Saeed et al., 2018), pig (Cottrell et al., 2020), rat (Alsoodeeri et al., 2020), and human (Khan et al., 2003;
Pandey et al., 2020) but no study in fish. Some authors investigated the effect of cinnamon in the growth and immune response of tilapia (Oreochromis niloticus) (Ahmad et al., 2011).

According to recently published aquaculture status (FAO 2020), the annual global production of rainbow trout as one of the most farmed salmonids worldwide has been 834 thousand tonnes. Iran produces at least $30 \%$ of this amount. In this way, according to the Iran Fishery Organization announcement in 2018, rainbow trout is the highest consumed species in this country.

The response of fish to herbal medicine in various levels of carbohydrates is unknown. This issue is more important for rainbow trout, which is sensitive to high carbohydrate levels in the diet. We hypothesized that cinnamon, as the most popular herb for glucoselowering and lipid-lowering effect, can alleviate the adverse impacts of including high levels of carbohydrate in diets. In this way, this study was designed to examine the impact of this herb on growth performance, body composition, blood biochemistry, hematology, digestive enzymes, and antioxidant system of rainbow trout.

Table 1. Formulation and proximate analyses of the experimental diets containing different carbohydrates and cinnamon levels.

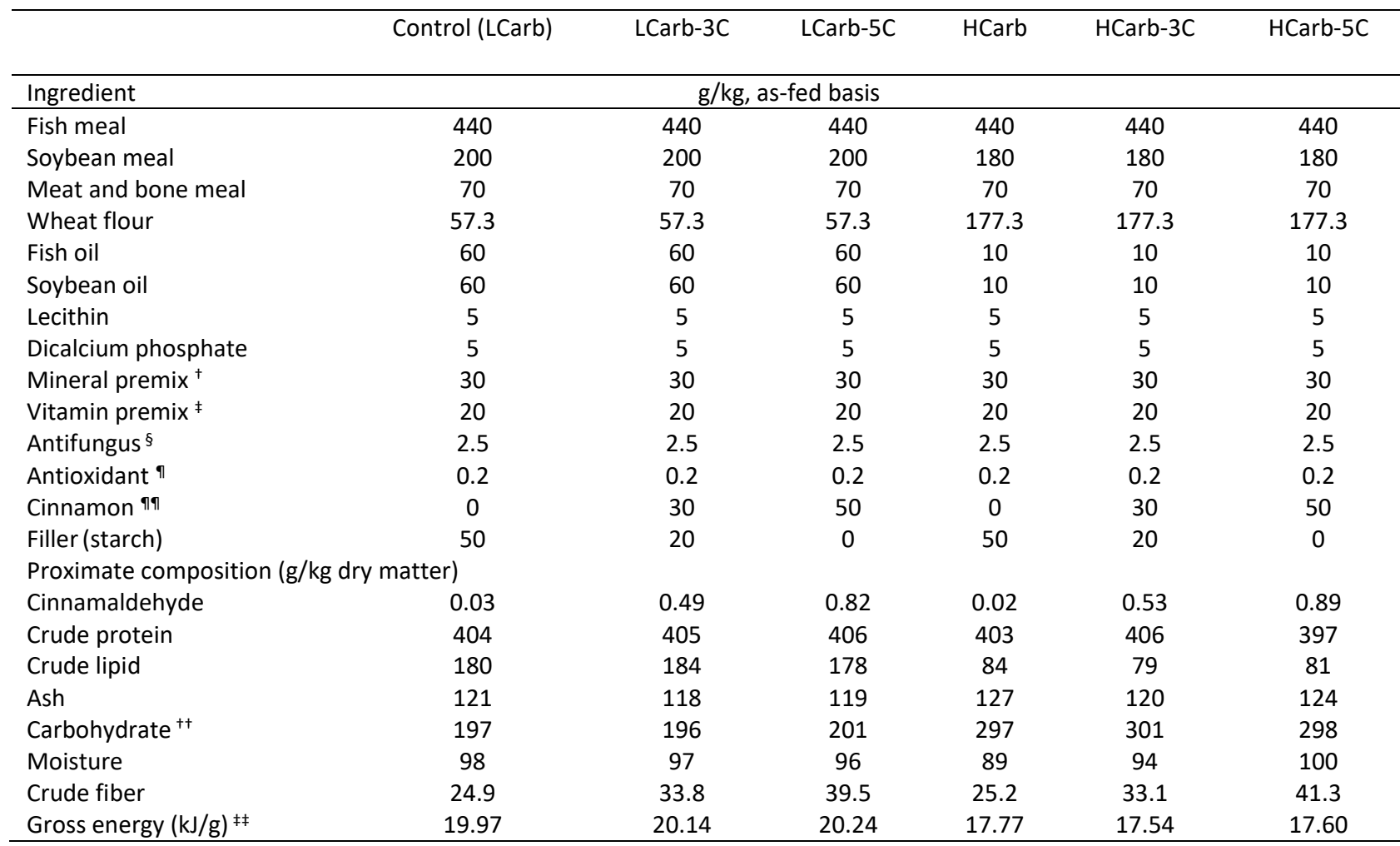

Diet components were purchased from the Mazandaran Animal \& Aquatic Feed (Sari, Mazandaran, Iran).

${ }^{+} 1 \mathrm{~kg}$ Mineral Supplementation contained: $\mathrm{Co}, 100 ; \mathrm{I}, 400$; se, 20; Zn, 10,000; Fe, 6,000; Cu, 600; Mn, 5,000

$\$ 5 \mathrm{~kg}$ Vitamin Supplementation 0.5\% contained: vitamin A 80,000 IU/ kg; vitamin D3 2,000 IU/kg; vitamin k $20 \mathrm{mg} / \mathrm{kg}$; thiamin $60 \mathrm{mg} / \mathrm{kg}$; riboflavin $60 \mathrm{mg} / \mathrm{kg}$; pyridoxine $100 \mathrm{mg} / \mathrm{kg}$; pantothenic acid $150 \mathrm{mg} / \mathrm{kg}$; niacin $300 \mathrm{mg} / \mathrm{kg}$; biothin $2 \mathrm{mg} / \mathrm{kg}$; folic acid $20 \mathrm{mg} / \mathrm{kg}$; vitamin B12 $0.1 \mathrm{mg} / \mathrm{kg}$; inositol $300 \mathrm{mg} / \mathrm{kg}$; ascorbic acid $600 \mathrm{mg} / \mathrm{kg}$; choline chloride $3000 \mathrm{mg} / \mathrm{kg}$.

$\S$ Anti fungi: Toxiban premix (Component: Alomino silicate, zeolite, bentonate, propionate ammonium)

"Antioxidant: Butylated hydroxytoluene (BHT).

กศ Cinnamon contained $101.0 \mathrm{~g} / \mathrm{kg}$ moisture, $44.1 \mathrm{~g} / \mathrm{kg}$ protein, $21.4 \mathrm{~g} / \mathrm{kg}$ fat, $32.6 \mathrm{~g} / \mathrm{kg}$ ash, and $282.3 \mathrm{~g} / \mathrm{kg}$ fiber.

${ }^{++}$Carbohydrate $=100$ - (crude protein + crude lipid + ash + moisture).

¥¥ Estimated gross energy was calculated based on $1 \mathrm{~g}$ crude protein being $23.6 \mathrm{kj}, 1 \mathrm{~g}$ crude fat being $39.5 \mathrm{kj}$, and $1 \mathrm{~g}$ carbohydrate being $17.2 \mathrm{kj}$. NRC (2011). Dietary treatments with different levels of carbohydrate and cinnamon: control/LCarb ( $200 \mathrm{~g} / \mathrm{kg}$ carbohydrate), LCarb-3C ( $200 \mathrm{~g} / \mathrm{kg}$ carbohydrate, $30 \mathrm{~g} / \mathrm{kg}$ cinnamon), LCarb-5C (200g/kg carbohydrate, $50 \mathrm{~g} / \mathrm{kg}$ cinnamon), HCarb (300 g/kg carbohydrate), HCarb-3C (300 g/kg carbohydrate, $30 \mathrm{~g} / \mathrm{kg}$ cinnamon), and HCarb-5C (300 g/kg carbohydrate, $50 \mathrm{~g} / \mathrm{kg}$ cinnamon). 


\section{Material and Methods}

\section{Analyzing Cinnamaldehyde in Diets}

As cinnamaldehyde forms $65 \%-80 \%$ of active compounds of cinnamon powder (Rao and Gan 2014), we measured it in diets. Cinnamaldehyde contents in cinnamon powder from the present study was 15.7 $\mathrm{mg} / \mathrm{g}$ powder. High performance liquid chromatography (HPLC) method was used, and cinnamaldehyde was detected at $275 \mathrm{~nm}$, and peak area was used for signals evaluation (Lungarini et al., 2008). The cinnamaldehyde contents of the experimental diets are reported in Table 1.

\section{Diet Preparation}

Six isonitrogenous (400 g crude protein $/ \mathrm{kg}$ feed) diets were formulated by Lindo software. The diet components were purchased from the Mazandaran Animal \& Aquatic Feed (Sari, Mazandaran, Iran). Freshpowdered cinnamon also was purchased from a local market (cinnamaldehyde contents were measured from this source). The treatments included control $(200 \mathrm{~g} / \mathrm{kg}$ carbohydrate, $0 \mathrm{~g} / \mathrm{kg}$ cinnamon), LCarb-3C (200 g/kg carbohydrate, $30 \mathrm{~g} / \mathrm{kg}$ cinnamon), LCarb-5C (200g/kg carbohydrate, $50 \mathrm{~g} / \mathrm{kg}$ cinnamon), HCarb (300 g/kg carbohydrate, $0 \mathrm{~g} / \mathrm{kg}$ cinnamon), HCarb-3C (300 g/kg carbohydrate, $30 \mathrm{~g} / \mathrm{kg}$ cinnamon), HCarb-5C (300 g/kg carbohydrate, $50 \mathrm{~g} / \mathrm{kg}$ cinnamon). As a previous study showed the maximum growth with the maximum powder dosage ( $15 \mathrm{~g} / \mathrm{kg}$ diet) in fish plus a chicken study (Toghyani et al., 2011), we selected upper levels (30 and $50 \mathrm{~g} / \mathrm{kg}$ diet) to illustrate the optimum dose of cinnamon powder for rainbow trout. The dietary ingredients were first dried and mixed carefully and became homogeneous. After complete mixing, liquid ingredients such as Kilka fish oil, soybean oil, and lecithin were weighed carefully and added gradually to the mixture. The resulting mixture was compressed by a meat grinder (Electrokar EC-1, Tehran, Iran) to form pellets with a 3 $\mathrm{mm}$ diameter. Then, pellets were spread out on a tray and dried in an oven to $\geq 90 \%$ dry matter at $60^{\circ} \mathrm{C}$ for 24 $48 \mathrm{~h}$. After drying the feeds, packed in suitable packages and kept at $4{ }^{\circ} \mathrm{C}$. The chemical compositions of experimental diets are presented in Table 1.

\section{Fish and Experimental Conditions}

For this experiment, a total of 360 juvenile rainbow trout (initial weight: $16.12 \pm 1.33 \mathrm{~g}$ ) were obtained from the Rangin Kaman farm (Sari, Mazandaran, Iran) and adapted two weeks with the experimental condition in Danesh Abzian Arya Mazand (Sari, Mazandaran, Iran). Eighteen 300-L fiberglass tanks within a semirecirculating system were adjusted for this experiment for six treatments. Throughout the trial, tank water was siphoned off daily $30-40 \%$ of water to remove feces and debris. Water quality parameters were regularly checked and kept in the standard range for the culture of rainbow trout throughout the 8-week experiment (temperature $14 \pm 0.6^{\circ} \mathrm{C}$; DO $7.4 \pm 0.35 \mathrm{mg} / \mathrm{L} ; \quad \mathrm{pH}$ $7.20 \pm 0.3$ ). Photoperiod was maintained at $12 \mathrm{D}: 12 \mathrm{~L}$, and fish were hand-fed three times daily to apparent satiation. The temperature was measured by mercury thermometer (Zomorodazma Company, Iran), dissolved oxygen by Cyberscan Eutech instruments (DO 110, Singapore), and $\mathrm{pH}$ by a $\mathrm{pH}$ meter (Hanna instrument, 8314, USA) (Hosseinpour Aghaei et al., 2018). Ammonia, nitrite, and nitrate $(0.11,0.01$, and $4.9 \mathrm{mg} / \mathrm{L})$ were measured by ASTM International D1426-08 and D386709 , respectively.

Table 2. Growth performance of rainbow trout fed experimental diets containing carbohydrate and cinnamon for eight weeks.

\begin{tabular}{|c|c|c|c|c|c|c|}
\hline Growth index & Control (LCarb) & LCarb-3C & LCarb-5C & HCarb & HCarb-3C & HCarb-5C \\
\hline Initial weight (g) & 16.31 & 16.02 & 16.21 & 15.89 & 16.28 & 16.04 \\
\hline Weight gain (g) & $54.86 \pm 2.74^{b}$ & $72.64 \pm 1.55^{a}$ & $73.17 \pm 5.62^{a}$ & $53.23 \pm 5.01^{b}$ & $53.76 \pm 2.09^{b}$ & $58.07 \pm 2.26^{a b}$ \\
\hline SGR (\%/day) & $2.63 \pm 0.24$ & $3.05 \pm 0.21$ & $3.04 \pm 0.28$ & $2.62 \pm 0.18$ & $2.60 \pm 0.17$ & $2.73 \pm 0.14$ \\
\hline FCR & $1.07 \pm 0.11$ & $0.94 \pm 0.12$ & $0.97 \pm 0.06$ & $1.05 \pm 0.10$ & $1.09 \pm 0.09$ & $0.99 \pm 0.12$ \\
\hline Feed consumption (FC) & $58.47 \pm 3.21^{b}$ & $68.25 \pm 3.47^{a}$ & $71.27 \pm 2.50^{a}$ & $55.87 \pm 3.98^{b}$ & $57.51 \pm 4.11^{b}$ & $56.50 \pm 3.55^{b}$ \\
\hline DFI (\%/day) & $2.39 \pm 0.53$ & $2.33 \pm 0.62$ & $2.41 \pm 0.45$ & $2.35 \pm 0.36$ & $2.38 \pm 0.24$ & $2.24 \pm 0.21$ \\
\hline Protein efficiency & $2.30 \pm 0.27$ & $2.63 \pm 0.24$ & $2.53 \pm 0.25$ & $2.36 \pm 0.20$ & $2.26 \pm 0.15$ & $2.54 \pm 0.16$ \\
\hline Lipid efficiency & $5.18 \pm 0.60$ & $5.78 \pm 0.54$ & $5.76 \pm 0.71$ & $5.18 \pm 0.54$ & $5.13 \pm 0.64$ & $5.58 \pm 0.57$ \\
\hline HSI (\%) & $1.12 \pm 0.09$ & $1.19 \pm 0.08$ & $1.01 \pm 0.04$ & $1.17 \pm 0.06$ & $1.09 \pm 0.08$ & $1.15 \pm 0.07$ \\
\hline VSI (\%) & $11.54 \pm 0.36$ & $11.10 \pm 1.06$ & $11.68 \pm 1.14$ & $11.52 \pm 0.76$ & $11.16 \pm 0.65$ & $11.49 \pm 0.82$ \\
\hline Condition factor & $1.04 \pm 0.13$ & $1.12 \pm 0.05$ & $1.11 \pm 0.06$ & $1.10 \pm 0.03$ & $1.02 \pm 0.05$ & $1.05+0.07$ \\
\hline Survival rate $(\%)$ & 100 & 100 & 100 & 100 & 100 & 100 \\
\hline
\end{tabular}

Feed intake (\%body weight.day $\left.{ }^{-1}\right)=100 \times$ feed consumed $(\mathrm{g}) /($ (initial weigh + final weight $) \times 0.5 \times$ days $)$

WG $(\%)=100 \times(($ final weight - initial weight $) /$ initial weight $)$

CF: Condition Factor $=\left(\right.$ final weight $(\mathrm{g}) /$ Length $\left.^{3}\right) \times 100$

SGR: Specific Growth Rate $=(($ Ln final weight - Ln initial weigh) $/$ During the total experimental period $(56$ days $)) \times 100$

FCR: Feed Conversion Ratio = Dry feed consumed (g) / WG (g)

PE/LE: Protein/Lipid Efficiency Ratio= Weight gain (g) / consumed protein/lipid (g)

HSI: Hepatosomatic Index $=($ Liver weight $(\mathrm{g}) /$ Body weight $(\mathrm{g})) \times 100$

VSI: Viscerosomatic Index $=($ Visceral weight (g) / Body weight $(\mathrm{g})) \times 100$

Survival $(\%)=$ (Number of fish in each group remaining at the end of experiment / initial number of fish) $\times 100$

Values are represented means \pm SDM of triplicate tanks; means without letter labels are not significantly different. The letters a, and $b$ indicate significant differences in the treatments according to Duncan's multiple range tests $(P<0.05)$. 


\section{Growth Performance}

At the end of the feeding trial, all fishes were fasted for 24 hours and were then anesthetized with the clove oil stock solution (50-70 ppm) (Esmaeili et al., 2017b). The survival rate and growth indices including feed consumption (FC), weight gain (WG), specific growth rate (SGR), FCR, protein efficiency (PE), lipid efficiency (LE), hepatosomatic index (HSI), visceral index (VSI), and condition factor (CF) were determined using standard methods and relationships. All the applied formulas are reported in the footnote of Table 2 . Also, three fishes per tank were randomly selected, and then their respective liver was sampled and weighed. We used whole fish, including its liver, for performing body composition analysis.

\section{Chemical Analysis}

The proximate composition of whole-body tissue samples was analyzed using AOAC methods (AOAC 2000). Briefly, crude protein was determined by the Kjeldahl method, using an automatic Kjeldahl system (Kjeltec Analyser unit 2300, Sweden). Crude lipid was analyzed with the Soxhlet extraction method (Soxtec 2050 FOSS Model, Switzerland). Moisture was determined by drying samples in an oven at $105^{\circ} \mathrm{C}$ for 12 h. A Nabertherm muffle furnace (Model K, Germany) was used for the determination of ash $\left(550^{\circ} \mathrm{C}\right.$ for $\left.4 \mathrm{~h}\right)$. Fiber content was analyzed with a fiber analyzer (VELP ${ }^{\circledR}$
Scientifica, Italy). Nitrogen-free extract plus fiber, representing carbohydrate, was calculated using the formula: carbohydrate $=100$ - (protein + fat + ash + moisture) (Aksnes and Opstvedt 1998). Gross energy of the diet was calculated according to the National Research Council (NRC 2011):

\section{Energy $(\mathrm{MJ} / \mathrm{kg})=($ protein $\times 23.6 \mathrm{~kJ} / \mathrm{g})+($ fat $\times 39.5 \mathrm{~kJ} / \mathrm{g})+$ (carbohydrate $\times 17.2 \mathrm{~kJ} / \mathrm{g}$ ) (Figure 1 ).}

\section{Digestive Enzyme Activities}

The stomach and whole intestines of each fish were homogenized on ice in an electric homogenizer. Amylase, lipase, and protease measurements were done in the collected digestive tracts from each fish. The total protein content of the supernatant was analyzed using the Bradford method (Bradford 1976), and bovine serum albumin (BSA) was used as a standard. Protease activity was measured as described previously (Hidalgo et al., 1999) using casein hydrolysis at $\mathrm{pH}$ 8. Enzyme reaction mixtures consisted of $1 \%(\mathrm{w} / \mathrm{v})$ casein in water $(0.25 \mathrm{ml})$, buffer $(0.25 \mathrm{ml})$, and enzyme sample $(0.1 \mathrm{ml})$ and were incubated for $1 \mathrm{~h}$ at $37^{\circ} \mathrm{C}$. The reaction was stopped by adding $0.6 \mathrm{ml}$ of $8 \%(\mathrm{w} / \mathrm{v})$ trichloroacetic acid. After holding for $1 \mathrm{~h}$ at $2^{\circ} \mathrm{C}$, samples were centrifuged at $1800 \times \mathrm{g}$ for $10 \mathrm{~min}$, and the absorbance of the supernatant was recorded at $280 \mathrm{~nm}$. Tyrosine was used as standard, and one unit of enzyme activity was defined as the amount of enzyme needed to catalyze the

Table 3. Proximate composition of whole-body ( $\mathrm{g} / \mathrm{kg}$ dry matter basis) of rainbow trout (Oncorhynchus mykiss) fed containing carbohydrate and cinnamon for eight weeks

\begin{tabular}{lllllll}
\hline & Control (LCarb) & LCarb-3C & LCarb-5C & HCarb & HCarb-3C & HCarb-5C \\
\hline Protein & $657.4 \pm 10.6$ & $668.9 \pm 17.2$ & $652.2 \pm 18.4$ & $659.8 \pm 12.7$ & $656.7 \pm 13.2$ & $664.1 \pm 11.8$ \\
Lipid & $251.7 \pm 22.3 \mathrm{ab}$ & $239.3 \pm 24.5 \mathrm{~b}$ & $253.3 \pm 16.4 \mathrm{ab}$ & $269.7 \pm 23.6 \mathrm{a}$ & $257.7 \pm 17.4 \mathrm{ab}$ & $258.2 \pm 15.5 \mathrm{ab}$ \\
Ash & $79.6 \pm 7.9$ & $77.3 \pm 7.2$ & $76.7 \pm 8.3$ & $82.5 \pm 6.4$ & $76.8 \pm 6.7$ & $81.7 \pm 7.9$ \\
Moisture & $734.2 \pm 12.1$ & $735.2 \pm 18.7$ & $729.8 \pm 11.9$ & $720.4 \pm 16.1$ & $728.7 \pm 11.3$ & $730.5 \pm 10.4$ \\
\hline
\end{tabular}

Values are represented means \pm SDM of triplicate samples; means without letter labels are not significantly different. The letters a, and $b$ indicate significant differences in the treatments according to Duncan's multiple range tests $(P<0.05)$.

Table 4. Hematological parameters of rainbow trout fed experimental diets containing carbohydrate and cinnamon for eight weeks.

\begin{tabular}{lcccccc}
\hline Hematology & Control (LCarb) & LCarb-3C & LCarb-5C & HCarb & HCarb-3C & HCarb-5C \\
\hline RBC $\left(\mathrm{X} 10^{6} / \mathrm{mm}^{-3}\right)$ & $1.10 \pm 0.13$ & $1.07 \pm 0.12$ & $1.06 \pm 0.09$ & $0.98 \pm 0.13$ & $0.99 \pm 0.21$ & $1.11 \pm 0.18$ \\
WBC $\left(\mathrm{X} 10^{3} / \mathrm{mm}^{-3}\right)$ & $19.95 \pm 1.41$ & $22.20 \pm 0.58$ & $22.68 \pm 1.04$ & $21.35 \pm 1.57$ & $20.34 \pm 2.31$ & $19.92 \pm 1.89$ \\
Haematocrit $(\%)$ & $30.54 \pm 2.76$ & $30.60 \pm 2.79$ & $29.47 \pm 2.12$ & $29.96 \pm 2.40$ & $30.03 \pm 3.44$ & $30.23 \pm 2.55$ \\
Haemoglobin $(\mathrm{g} / \mathrm{dl})$ & $9.12 \pm 0.64$ & $9.98 \pm 0.72$ & $9.28 \pm 0.79$ & $9.09 \pm 1.82$ & $8.96 \pm 0.72$ & $9.41 \pm 1.02$ \\
MCV (fl) & $277.63 \pm 29.11$ & $285.98 \pm 50.55$ & $278.02 \pm 27.84$ & $305.71 \pm 36.06$ & $303.33 \pm 32.45$ & $272.34 \pm 25.77$ \\
MCH (pg) & $82.91 \pm 22.28$ & $93.27 \pm 22.72$ & $87.55 \pm 20.43$ & $92.44 \pm 15.54$ & $90.50 \pm 11.56$ & $84.77 \pm 12.69$ \\
MCHC (\%) & $29.86 \pm 12.54$ & $32.61 \pm 9.83$ & $31.49 \pm 5.26$ & $30.24 \pm 6.05$ & $29.84 \pm 8.14$ & $31.13 \pm 7.50$ \\
Blood performance & $62.70 \pm 3.40^{\mathrm{ab}}$ & $67.10 \pm 2.74^{\mathrm{a}}$ & $65.73 \pm 2.92 \mathrm{ab}$ & $63.38 \pm 2.55^{\mathrm{ab}}$ & $62.47 \pm 3.11^{\mathrm{b}}$ & $62.91 \pm 2.00^{\mathrm{ab}}$ \\
\hline
\end{tabular}

Mean corpuscular volume $(\mathrm{MCV})(\mathrm{fl})=\left(\right.$ Haematocrit $\left./\left(\mathrm{RBC} \times 10^{6} / \mathrm{mm}^{-3}\right)\right) \times 10$

Mean corpuscular haemoglobin $(\mathrm{MCH})(\mathrm{pg})=$ Haemoglobin $/ \mathrm{RBC} \times 10^{6} / \mathrm{mm}^{-3} \times 10$

MCHC $=$ Haemoglobin/Haematocrit $\times 100$

Blood performance $=\mathrm{RBC}\left(\mathrm{X} 10^{6} / \mathrm{mm}^{-3}\right)+\mathrm{WBC}\left(\mathrm{X} 10^{3} / \mathrm{mm}^{-3}\right)+$ Haematocrit $(\%)+$ Haemoglobin $(\mathrm{g} / \mathrm{dl})+$ total protein $(\mathrm{g} / \mathrm{dL})$.

Blood performance was introduced by Moha Esmaeili for the first time (Montazeri Parchikolaei et al., 2021).

Values are represented means \pm SDM of triplicate tanks; means without letter labels are not significantly different. The letters $a$, and $b$ indicate significant differences in the treatments according to Duncan's multiple range tests $(P<0.05)$. 
formation of $1 \mu \mathrm{g}$ of tyrosine per $1 \mathrm{~min}$. Lipase activity was assayed by using $0.53 \mathrm{mM}$ pnitrophenyl myristate dissolved in $0.25 \mathrm{mM}$ Tris - $\mathrm{HCl}, 0.25 \mathrm{mM} 2$ - methoxy ethanol and $5 \mathrm{mM}$ sodium cholate buffer $(\mathrm{pH}=9.0)$. Briefly, $5 \mu \mathrm{L}$ of enzyme extract in $0.5 \mathrm{ml}$ of the substrate was incubated for $15 \mathrm{~min}$ at $30^{\circ} \mathrm{C}$. The reaction was stopped by the addition of $0.7 \mathrm{~mL}$ of acetone: $\mathrm{n}$-heptane (5: 2), the extract centrifuged for $3 \mathrm{~min}$ at $6080 \mathrm{~g}$ and $4^{\circ} \mathrm{C}$, and absorbance was recorded at $405 \mathrm{~nm}$. In the blank, acetone: $\mathrm{n}$-heptane was added to the substrate before the addition of enzyme extract (lijima et al., 1998). Specific activity (U) was expressed as:

Lipase activity $=(A($ sample $(280 \mathrm{~nm})) \times$ value $\times 1000) /(15$ $\times 16500 \times$ mg protein)
Amylase activity was estimated by using $1 \%$ starch dissolved in $100 \mathrm{ml}$ buffer containing $20 \mathrm{mM}$ sodium phosphate and six $\mathrm{mM} \mathrm{NaCl}(\mathrm{pH}=6.9)$. Briefly, $250 \mu \mathrm{L}$ of enzyme extract was incubated for $3-4 \mathrm{~min}$ at $25^{\circ} \mathrm{C}$. This was followed by the addition of $0.5 \mathrm{ml}$ dinitrosalicylic acid (DNS) and incubation for $5 \mathrm{~min}$ at $100^{\circ} \mathrm{C}$ and the addition $5 \mathrm{ml}$ water. Absorbance was recorded from the change at $540 \mathrm{~nm}$, and the quantity of maltose released was determined from a standard curve prepared from maltose solution. One unit was calculated as the quantity of enzyme that released one $\mu \mathrm{mol}$ of maltose in 1 min (Bernfeld 1955; Worthington 1991). Specific activity (U) was expressed as:

Amylase activity $=($ Maltose released $(\mu \mathrm{mol})) /(3 \times \mathrm{mg}$ protein)

Table 5. Blood biochemistry in the serum of rainbow trout fed experimental diets containing carbohydrate and cinnamon for eight weeks.

\begin{tabular}{lcccccc}
\hline Blood chemistry & Control (LCarb) & LCarb-3C & LCarb-5C & HCarb & HCarb-3C & HCarb-5C \\
\hline Glucose $(\mathrm{mg} / \mathrm{dL})$ & $85.37 \pm 1.75^{\mathrm{a}}$ & $65.40 \pm 1.32^{\mathrm{bc}}$ & $68.61 \pm 5.05^{\mathrm{b}}$ & $89.96 \pm 2.43^{\mathrm{a}}$ & $59.76 \pm 3.82^{\mathrm{c}}$ & $66.32 \pm 5.51^{\mathrm{b}}$ \\
Cholesterol (mg/dL) & $95.42 \pm 6.44^{\mathrm{a}}$ & $71.25 \pm 9.32^{\mathrm{c}}$ & $79.76 \pm 6.79^{\mathrm{bc}}$ & $80.10 \pm 7.45^{\mathrm{bc}}$ & $74.21 \pm 6.35^{\mathrm{c}}$ & $89.63 \pm 7.29^{\mathrm{ab}}$ \\
Triglyceride $(\mathrm{mg} / \mathrm{dL})$ & $215.66 \pm 23.55$ & $199.88 \pm 16.12$ & $214.70 \pm 15.00$ & $210.88 \pm 19.27$ & $202.76 \pm 18.06$ & $205.62 \pm 17.45$ \\
Total protein $(\mathrm{g} / \mathrm{dL})$ & $1.99 \pm 0.36^{\mathrm{b}}$ & $3.25 \pm 0.79^{\mathrm{a}}$ & $3.24 \pm 0.61^{\mathrm{a}}$ & $2.00 \pm 0.28^{\mathrm{b}}$ & $2.15 \pm 0.41^{\mathrm{b}}$ & $2.24 \pm 0.51^{\mathrm{b}}$ \\
Albumin $(\mathrm{g} / \mathrm{dL})$ & $2.01 \pm 0.50^{\mathrm{b}}$ & $2.13 \pm 0.47$ & $2.05 \pm 0.19$ & $2.57 \pm 0.34$ & $2.46 \pm 0.46^{\mathrm{a}}$ & $1.90 \pm 0.34$ \\
HDL $(\mathrm{g} / \mathrm{dL})$ & $47.46 \pm 2.10^{\mathrm{b}}$ & $53.66 \pm 2.97^{\mathrm{ab}}$ & $50.25 \pm 3.50^{\mathrm{b}}$ & $52.30 \pm 2.88^{\mathrm{ab}}$ & $56.71 \pm 3.24^{\mathrm{a}}$ & $50.02 \pm 4.04^{\mathrm{b}}$ \\
LDL $(\mathrm{g} / \mathrm{dL})$ & $43.22 \pm 3.59^{\mathrm{a}}$ & $19.75 \pm 4.11^{\mathrm{c}}$ & $25.69 \pm 4.56^{\mathrm{c}}$ & $25.50 \pm 3.92^{\mathrm{c}}$ & $19.91 \pm 3.28^{\mathrm{c}}$ & $33.04 \pm 3.77^{\mathrm{b}}$ \\
HDL/LDL & $1.05 \pm 0.29^{\mathrm{c}}$ & $2.72 \pm 0.26^{\mathrm{a}}$ & $1.96 \pm 0.15^{\mathrm{bc}}$ & $2.05 \pm 0.28^{\mathrm{b}}$ & $2.85 \pm 0.30^{\mathrm{a}}$ & $1.52 \pm 0.24^{\mathrm{bc}}$ \\
Insulin (mIU/ml) & $10.25 \pm 2.22$ & $9.03 \pm 1.45$ & $9.83 \pm 2.17$ & $10.04 \pm 2.75$ & $8.86 \pm 3.20$ & $10.02 \pm 2.91$ \\
\hline
\end{tabular}

Values were represented means \pm SDM of triplicate tanks; means without letter labels are not significantly different. The letters $a, b$, and $c$ indicate significant differences in the treatments according to Duncan's multiple range tests $(P<0.05)$.
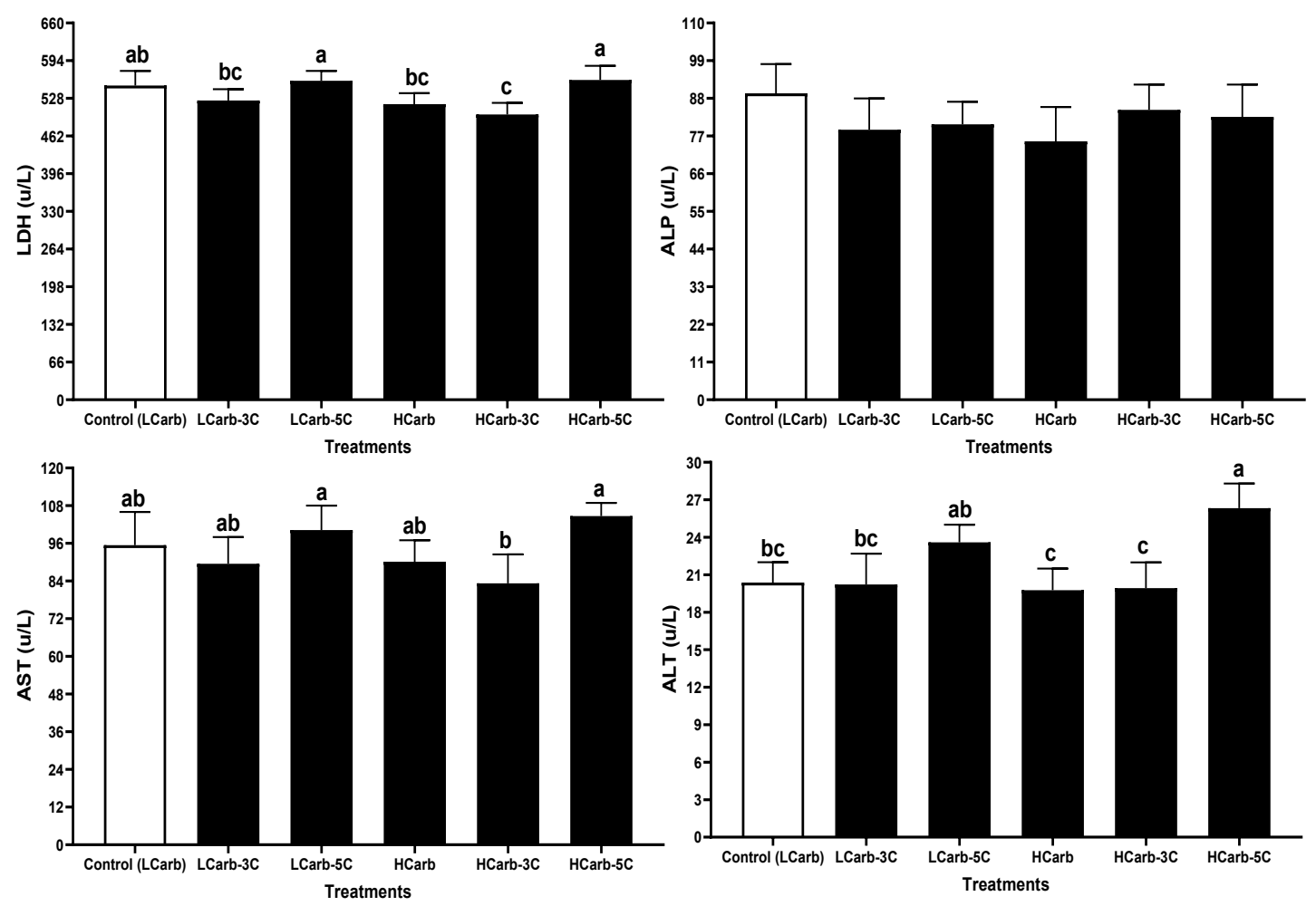

Figure 1. Lactate dehydrogenase (LDH), alkaline phosphatase (ALP), aspartate aminotransferase (AST), and alanine aminotransferase (ALT) activities in serum of juvenile rainbow trout fed experimental diets containing different levels of carbohydrate and cinnamon. Letters $a, b$, and $c$ indicate significant differences in treatment, according to Duncan's multiple range tests $(\mathrm{P}<0.05)$. 


\section{Hematology, Biochemistry, and the Antioxidant Parameters}

\section{Blood Collection and Sample Preparation}

Seven fish from each tank were sampled for hematological, blood biochemistry, and antioxidant analyses. For preventing stress, fish were anesthetized with a stock solution of clove oil $(50 \mathrm{mg} / \mathrm{L})$ (Esmaeili et al., 2017b), and blood samples were collected quickly by venipuncture of the caudal vein using a sterile 5-ml syringe. In the next step, blood was kept in the fridge for $2 \mathrm{~h}$ for blood clotting, and then serum was collected after centrifuging in $3000 \times \mathrm{g}$ at $4^{\circ} \mathrm{C}$ (Esmaeili et al., 2017b).

\section{Hematology Profile}

Red blood cells (RBCs) were counted in a Neubauer hemocytometer after diluting whole blood with Natt, M.P., and C.A. Herrick solution (1:200), containing $0.1 \mathrm{~g}$ of brilliant cresyl blue, $3.8 \mathrm{~g}$ of sodium citrate, and 0.2 $\mathrm{ml}$ of $37 \%$ formaldehyde in $100 \mathrm{ml}$ of distilled water. We counted five central compartments of the middle square of the Neubauer chamber, and the results were multiplied by 10,000 . Four marginal squares in the Neubauer chamber were used to count white blood cells (WBCs) after the blood was diluted 1:50 with Natt, M.P., and C.A. Herrick solution, and the results were multiplied by 50 (Kenari et al., 2013). Hemoglobin was measured using the cyanmethemoglobin method. The
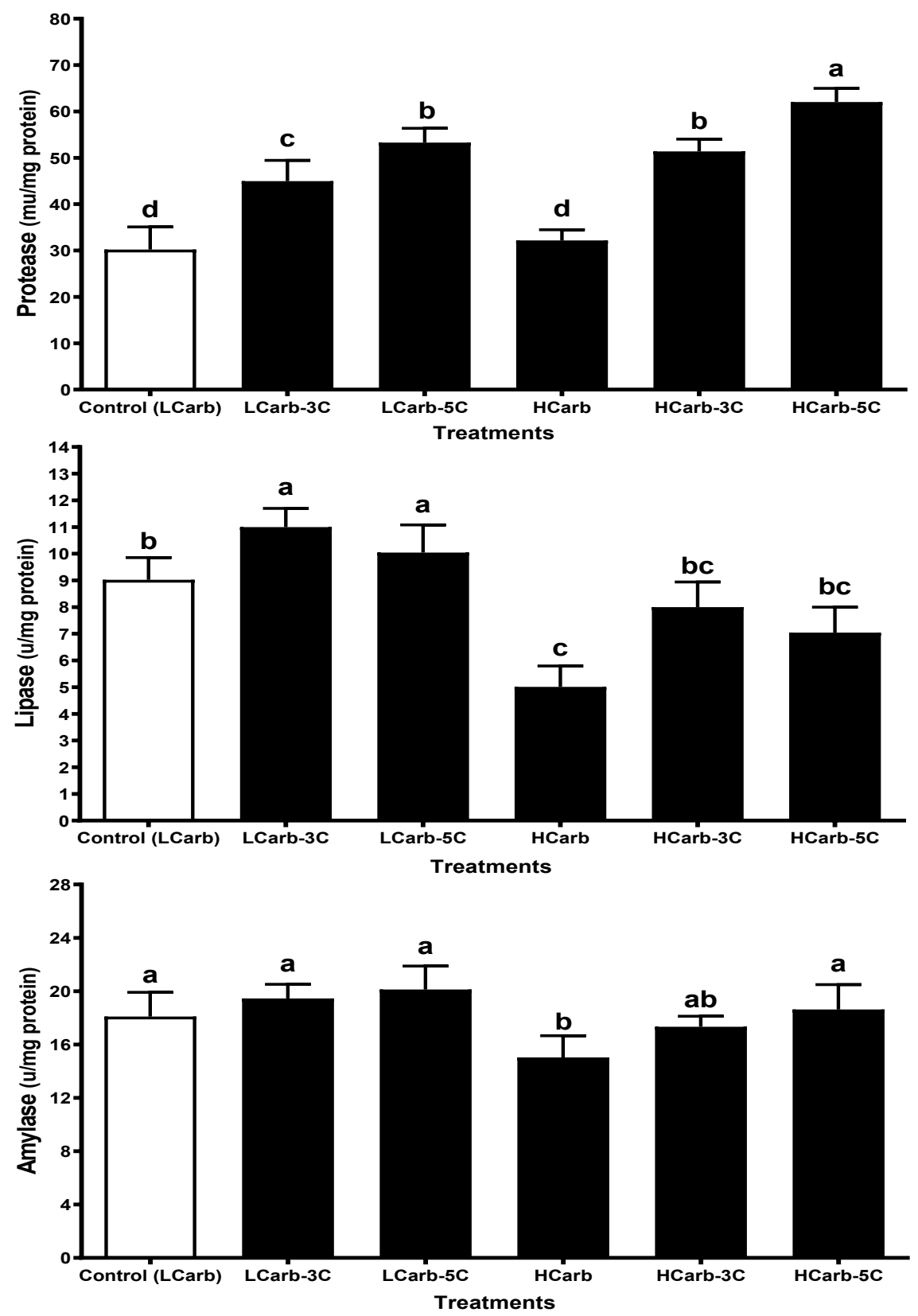

Figure 2. Protease, lipase, and amylase activity of the digestive tract of juvenile rainbow trout fed experimental diets containing different levels of carbohydrate and cinnamon. Letters $a, b, c$, and d indicate significant differences in treatment, according to Duncan's multiple range tests $(P<0.05)$. 
uncoagulated blood $(20 \mu \mathrm{l})$ was mixed with $5 \mathrm{ml}$ of Drabkin's solution and placed in a dark place for $5 \mathrm{~min}$. Afterward, it was read (in $\mathrm{g} / \mathrm{dl}$ ) by a spectrophotometer at $540 \mathrm{~nm}$ (UNICO, model 2100, USA). Haematocrit (Hct) was determined by the microhematocrit method. First, more than two-thirds of Hct capillary tubes were filled with uncoagulated blood. The tubes were centrifuged at $13000 \times \mathrm{g}$ for $5 \mathrm{~min}$ in a microhematocrit apparatus, and then hematocrit values were read using a specific graded sheet (Řehulka et al., 2004). Mean corpuscular volume (MCV), mean corpuscular hemoglobin (MCH), $\mathrm{MCHC}$, and blood performance were calculated according to the reported formula in footnote Table 4.

\section{Blood Biochemistry, Liver Enzymes, and Antioxidant Activity}

Glucose, cholesterol, triglyceride, total protein, albumin, HDL, and LDL assays were done with the kits from Pars Azmun Company (Pars Azmun, Karaj, Iran) according to the protocols. Insulin was measured with a commercial kit (Fish Insulin, ELISA Kit, CUSABIO) according to the protocol. $L D H, A L P, A L T$, and AST in serum were measured with an autoanalyzer (Eppendorf, EPOS, Germany). The antioxidant enzymes (SOD and
CAT) in serum were determined using an analysis ELISA kits (ZellBio, $\mathrm{GmbH}$, Germany) according to the protocol.

\section{Statistical Analysis}

Our experiment was designed and adjusted according to a completely randomized design. ShapiroWilk and Levene's tests were used to test for normality and homogeneity of variance, respectively. All data were analyzed by one-way analysis of variance (ANOVA) using SPSS (version 22.0 for Windows). Duncan's multiple range tests were used to assess differences among six treatments in growth performance factors, body composition, hematology, blood biochemistry, digestive enzymes, and antioxidant activities.

\section{Results and Discussion}

\section{Growth Performance}

Although numerous studies investigated the effect of cinnamon on animal and human physiology and growth, the exact mechanism is unknown. Cinnamon, as the most well-known herbal medicine for glucoselowering and lipid-lowering effect, was selected for this
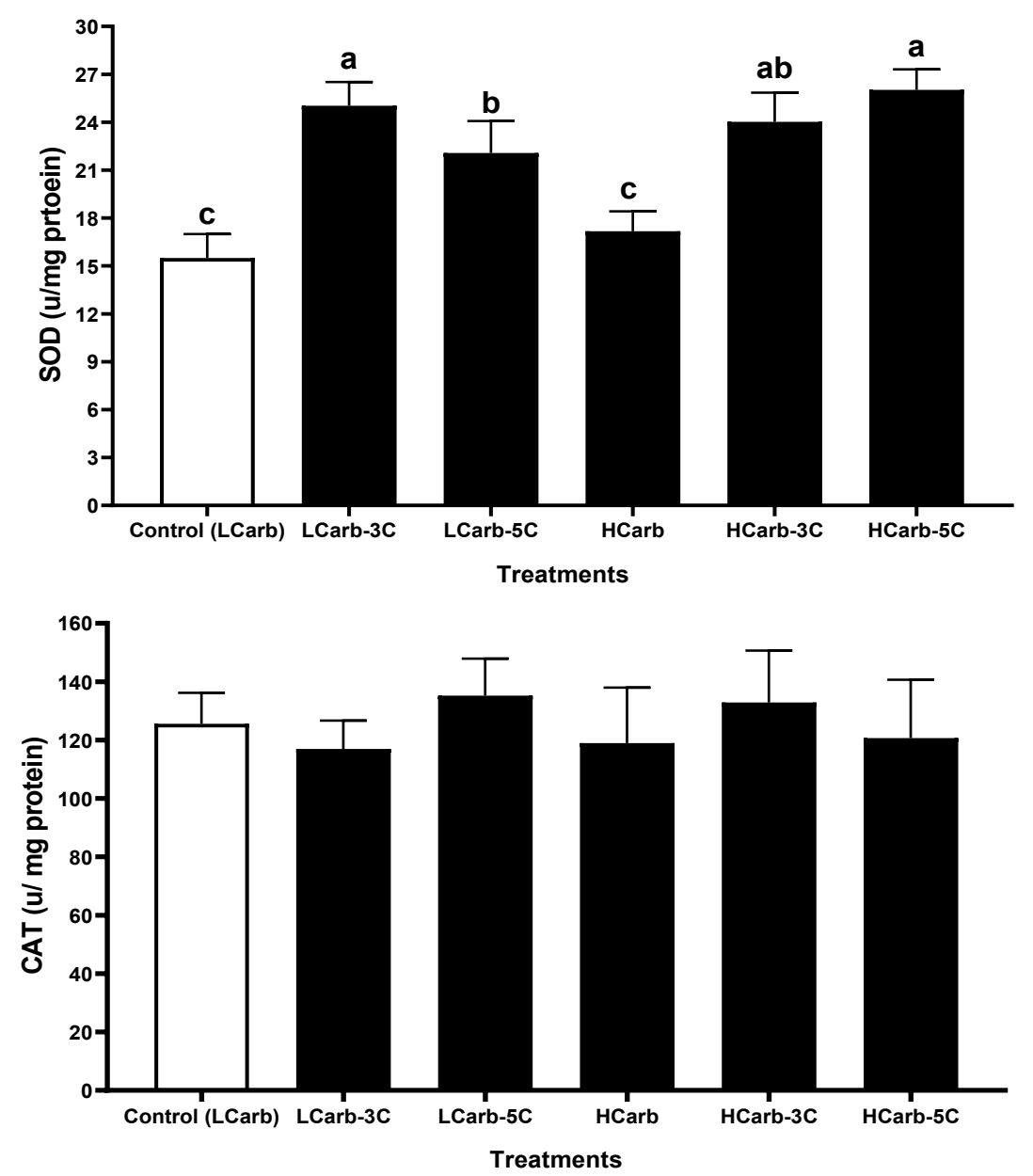

Figure 3. SOD and catalase activity in serum of juvenile rainbow trout fed experimental diets containing different levels of carbohydrate and cinnamon. Letters $a, b$, and c indicate significant differences in treatment, according to Duncan's multiple range tests $(\mathrm{P}<0.05)$. 
research. Also, we selected rainbow trout as they cannot tolerate high carbohydrate levels in the diet. According to Table 2, there was no significant difference in SGR, FCR, DFI, protein and lipid efficiency, HSI, VSI, CF, and survival rate values among treatments. Rainbow trout fed dietary LCarb-3C (72.64) and LCarb-5C (73.17) had significantly higher numbers of WG (g) as compared with others but not HCarb-5C (58.07) $(\mathrm{P}<0.05)$ (Table 2). Although the difference was not significant, FCR in LCarb-3C (0.94) was lower than the control (1.07) and HCarb-3C (1.09) group (Table 2). Also, FC followed a trend like WG, and it shows fish that ate more feed grew more. In tilapia (10 g/kg nanocinnamon) (Abdel-Tawwab et al., 2018; Ahmad et al., 2011), chicken (0.25-1 g/kg powder) (Singh et al., 2014; Toghyani et al., 2011), and quail (200 mg/kg cinnamon oil) (Mehdipour et al., 2013) similar outputs were observed. Also, researchers supplemented cinnamaldehyde (the main active component of cinnamon) to fish diets, and as a result, growth, and amino acid transporters genes were overrepresented (Zhou et al., 2020). By looking at the literature, a wide range of variety can be seen in optimum dosage showing more research is required.

The main reason for improving growth performance by cinnamon in our study is unknown. Some ideas can be proposed, (i): improved digestion and nutrient digestibility leading to improved nutrient utilization. Digestive enzyme activity somehow confirmed this hypothesis; (ii): balanced lipid and carbohydrate hemostasis. Blood chemistry results confirmed this issue similar to several works in other animals and human (Goel and Mishra 2020; Khan et al., 2003; Sierra-Puente et al., 2020); (iii): well-known as a potent antioxidant and immune stimulator in fish in other animals (Abdel-Tawwab et al., 2018; Ahmad et al., 2011; Toghyani et al., 2011) which can indirectly improve growth as it happened in our study. However, more digestibility, hormonal, and bacterial studies are needed to illustrate the aforementioned phenomena. The present research is preliminary work, and in future investigations, we would focus on these points. Supplementation of too much cinnamon cause bitterness and astringency taste and potentially reduce feed intake (Bennick 2002). However, in rainbow trout, no sign of adverse effect on feed intake was observed, and it seems that fish can digest $50 \mathrm{~g} / \mathrm{kg}$ cinnamon without any problem related to palatability. Rainbow trout were fed in apparent satiation levels to make sure we can monitor any adverse effect of cinnamon on feed intake. Interestingly, no study was found in other animals to report decreasing feed intake with supplementing too much cinnamon to the experimental diets. Accordingly, this herb increased feed intake in mice by increasing the neuropeptide $Y$ gene expression in the hypothalamus (Ogawa et al., 2020). However, more studies on fish are necessary to illustrate this issue. Growth performance in high-carb diets was not decreased as compared with the control showing that rainbow trout can tolerate carbohydrates in diets up to
$300 \mathrm{~g} / \mathrm{kg}$. However, it worth highlighting that the fiber contents of diets were lower than $40 \mathrm{~g} / \mathrm{kg}$. Cinnamon improved growth performance just in LCarb groups. This study is the first work illustrating that the nutrient contents of diets play a crucial role in the growthpromoting effect of herbs. In general, we suggest 30 $\mathrm{g} / \mathrm{kg}$ in a low carbohydrate diet as the optimum level for providing maximum growth performance in rainbow trout.

\section{Chemical Composition of the Body}

Chemical composition of fish is a major determinant for customers as they prefer to buy and eat fish with fewer lipids but high levels of omega 3 as well as more protein contents. A wide range of internal and external factors such as age, gender, size, water quality, season, and geographical differentiate the chemical composition. Still, the main reason usually comes from the diet (Shearer 1994). Rainbow trout was fed by the dietary LCarb-3C had lower values of lipid $(239.3 \mathrm{~g} / \mathrm{kg})$ in comparison with HCarb treatment $(P<0.05)$ (Table 3$)$. Also, there was no significant difference in protein, ash, and moisture contents among the treatments. Lipid composition is one of the main indicators of the flesh quality of aquatic animals, as they are the most abundant source of omega 3 (Innes and Calder 2020). The result of the present study showed consistency with other data in barberry (Ramezanzadeh et al., 2020b) and garlic (Esmaeili et al., 2017a). However, some studies reported increased lipid contents in the body when fish fed dietary dill (Zeilab Sendijani et al., 2020). Blood biochemistry related to lipid metabolism (Ch, TG, and $\mathrm{HDL}$ ) confirmed these results, and for the first time, we can report the lipid-lowering and glucose-lowering effect of cinnamon in fish. Lipid-lowering effects of cinnamon in other animals and humans were well reported (Rahman et al., 2013; Santos and da Silva 2018) (Maierean et al., 2017). Although it was not significant, the inclusion of high carbohydrates to rainbow trout diets increased lipid contents in the body, which is compatible (Brauge et al., 1994) and incompatible with other studies (Austreng et al., 1977).

\section{Hematology and Blood Biochemistry}

Hematology and biochemistry parameters in the blood are relevant factors for monitoring fish status during environmental and nutritional changes (Fazio 2019). These parameters in fish were influenced by multiple factors such as species, size, age, physiological status, environmental conditions, and diet (quantity and quality, basal diet ingredients, protein source, vitamins, herbal medicine). The cinnamon inclusion did not elevate the RBC, WBC, hematocrit, hemoglobin, MCV, $\mathrm{MCH}$, and $\mathrm{MCHC}$ contents. However, blood performance in rainbow trout fed dietary LCarb-3C (67.10) was significantly higher than those that were fed by the HCarb-3C diet $(P<0.05)$ (Table 4). Moha Esmaeili 
introduced blood performance as a new hematological factor for aquaculture studies, which is a sum of the RBC, WBC, hematocrit, hemoglobin, and total protein (Montazeri Parchikolaei et al. 2021). Interestingly, this factor worked well in our research as well, so that while there was no significant difference among each element, this factor was significantly higher in the HCarb-3C group (this group had the highest growth as well). In beluga (Huso huso) also similar results were observed, and blood performance positively correlated with growth (Montazeri Parchikolaei et al., 2021). The results of hematology (no change in $R B C, W B C$, hematocrit, and hemoglobin) in rainbow trout were not surprising as cinnamon usually is not well-known for improving immunohematology parameters. Like our results, the authors did not find any significant difference in hematological factors in cinnamon-fed chickens (Toghyani et al., 2011). However, the LCarb-3C group can be considered as the high-performance treatment regarding hematological factors.

In the present study, cinnamon decreased glucose, cholesterol, and LDL; and increased total protein, HDL, and HDL/LDL ratio. More precisely, individuals fed control and HCarb diets had significantly higher glucose (85.37, $89.96 \mathrm{mg} / \mathrm{dL}$ ) as compared with those fed cinnamon-supplemented diets, respectively $(P<0.05)$ (Table 5). Also, the control group had the highest cholesterol $(95.42 \mathrm{mg} / \mathrm{dL}$ ) and LDL (43.22) contents as compared to other treatments $(P<0.05)$. Interestingly, the total protein in LCarb-3C (3.25) and LCarb-5C (3.24) groups, which have higher growth as well, was higher than other groups $(P<0.05)$. Finally, cinnamon increased HDL/LDL level in fish fed dietary LCarb-3C (2.72) and HCarb-3C (2.85) as compared to control $(P<0.05)$. Cinnamon is the most well-known herbal medicine for lowering glucose and cholesterol. Several studies in humans and different animals have reported these effects, which we already mentioned to a few of them in the introduction section. Accordingly, similar results were observed in rainbow trout, and for the first time, these effects on fish are reported. Cinnamon improves lipid-related blood biochemistry by directly affecting lipid metabolism. Inhibiting hepatic HMG-CoA reductase activity, which declined cholesterol production in the liver and suppressed lipid peroxidation (Baker et al., 2008), has been one of the primary mechanisms. Besides, elevated HDL in our study can be due to increasing lecithin cholesterol acyltransferase activity (crucial for blood lipid regulation) (Nakhjavani et al., 2020). This plant mimics the insulin effect via decreasing glucose absorption from the intestine and increasing the expression of insulin receptor genes, IGF1 signaling, and glucose uptake by adipose tissues. However, this herb, with changing more than 30 different pathways, can do the lowering effect of cholesterol and glucose, which was reviewed elsewhere (Mollazadeh and Hosseinzadeh 2016). While needed more research in molecular and gene levels, it seems that in cinnamon-fed fishes, improved blood biochemistry probably has been a reason for growth improvement through some of the pathways, as mentioned earlier.

Although no trend in data related to liver function enzymes ( $L D H, A L P, A L T$, and AST) in serum was found, rainbow trout fed dietary HCarb-5C and LCarb-5C had higher value of LDH $(558.79,560.20), \operatorname{ALT}(23.60,26.32)$, and AST $(100.25,104.67)$, respectively when compared with other groups $(P<0.05)$. These enzymes are involved in the detoxification of the liver, and we can propose that individuals fed the highest level of cinnamon in our study tried to detoxify the liver from some toxic compounds. The toxicity of several toxic compounds in cinnamon was reviewed elsewhere (Higaki et al., 2018; Lee et al., 2008). However, the contents of toxic compounds perhaps were not too much as the growth in cinnamon-fed fishes was higher. Consequently, LCarb$3 \mathrm{C}$ and LCarb-5C treatments were high performance in most of the investigated blood biochemistry factors.

\section{Digestive Enzymes}

It is reported that some herbal medicines are able to improve nutrient digestion and absorption. They do it via two main mechanisms, (i): elevation of bile acid secretion that has a key role in lipid digestion and absorption, (ii): facilitating digestion and absorption of proteins, carbohydrates, and lipids by stimulating the activities of the digestive enzymes (Platel and Srinivasan 2004). Generally, cinnamon stimulated the digestive enzyme in rainbow trout. Protease activity $(\mathrm{U} / \mathrm{mg}$ protein) in the LCarb-3C (44.98), LCarb-5C (53.29), HCarb-3C (51.36), and HCarb-5C (62.03) were statistically higher than the unsupplemented groups $(P<0.05)$ (Figure 2). Fish fed the LCarb-3C (11.00) and LCarb-5C (10.04) diets displayed higher lipase activity than those fed other feeds $(P<0.05)$. Surprisingly, fish fed dietary HCarb (15.03) exhibited a lower content of amylase when compared with other groups but not HCarb-3C (Figure 2). Various factors can affect digestive enzymes, such as light (Cuvier-Péres et al., 2001; Hou et al., 2019), stocking density (Wang et al., 2019), and carbohydrate quantity and quality in diets (Zhang et al., 2019) in fish. As temperature, light, and stocking density were similar between treatments, diets were considerably influenced digestive enzymes in the current work. Recently, Zhou et al. (2020) showed that cinnamaldehyde increased the digestion and absorption capacity by increasing the activities of intestinal and hepatopancreas digestive enzymes and intestinal brush border enzymes in grass carp (Ctenopharyngodon idella). Also, cinnamaldehyde upregulated amino acid transporters (AATs) in the intestine of this fish. Similarly, researchers demonstrated that dietary cinnamon nanoparticles elevated the activities of protease, amylase, and lipase in tilapia (Abdel-Tawwab et al., 2018). The results of our study are somehow consistent with their works. One reason for the improvement in digestive enzyme activity in fish fed the cinnamon diets could be attributed to the antioxidant properties of this 
herb. Results of antioxidant activities in the present research are a further line of evidence. Modifying the structure and function of digestive organs by improving antioxidant defense has been well reported (Sen and Chakraborty 2011).

In the present study, however, fish with higher growth performance had higher activity of digestive enzymes as well. Similarly, many investigators reported stimulating digestive enzymes enhanced growth (Esmaeili et al., 2017a; Sankar et al., 2017), while others found no direct relationship (Lemieux et al., 1999; Ramezanzadeh et al., 2020b).

\section{Antioxidant Activities}

Measuring antioxidant enzymes like SOD and CAT in fish can be useful markers for monitoring fish health status. These days, they are common-investigated factors in aquaculture (More than 2000 records, according to Scopus). SOD and CAT enzymes play vital roles in protecting cells against uncontrolled oxidative processes, leading to radical damage of superoxide and $\mathrm{H}_{2} \mathrm{O}_{2}$ (Martínez-Álvarez et al., 2005). In the present study, SOD activities were significantly higher in fish was fed by cinnamon diets. Precisely, rainbow trout fed dietary control (15.50) and the HCarb (17.16) had substantially lower values as compared with those fed cinnamon diets $(P<0.05)$ (Figure 3$)$. These results also showed increasing carbohydrate levels in diets did not differ SOD and CAT activity (Figure 3). Similar to our works, increasing SOD and/or CAT in rainbow trout fed lemon balm (Melissa officinalis) (Bilen et al., 2020), lemon verbena (Aloysia citrodora) (Hoseinifar et al., 2020), rosemary (Karataş et al., 2020), and dill (Zeilab Sendijani et al., 2020) were reported. Also, AbdelTawwab et al. (2018) reported an increase in these enzymes when tilapia fed nanocinnamon. On the other hand, so few studies reported decreasing SOD and CAT activities in rainbow trout when they were fed by ginger (Zingiber officinale) (Zargar et al., 2020). Cinnamon has a strong antioxidant activity, and this effect was reported well in different animals and humans (Abo Ghanima et al., 2020; Bastos et al., 2017). When we match the antioxidant enzymes and liver function enzymes, it can be concluded that cinnamon helped rainbow trout to keep homeostasis related to oxidative stress at an optimum level. This contributed to fish growing better as in our study and others were observed; higher antioxidants activities were usually in parallel with high growth performance. Also, elevated digestive enzymes were other evidence that oxidative stress was well-controlled with cinnamon and probably caused higher growth performance.

\section{Conclusion}

Conclusively, regarding growth performance, body composition, hematological parameters, blood biochemistry, digestive enzymes, and antioxidant activity, the LCarb-3C group had higher performance. For the first time, we reported the glucose-lowering and lipid-lowering effects of cinnamon in fish. Having a higher level of blood performance, HDL, total protein, digestive enzymes, and antioxidant activity can be some reasons for increasing growth in this treatment. Also, the glucose-lowering and lipid-lowering effects of this herb probably caused rainbow trout to keep optimum metabolic hemostasis for growth. In future research, focusing on digestibility, immune response, and gene expression is suggested to see how these factors contribute to improving growth performance.

\section{Ethical Statement}

All procedures involving animals were conducted according to the Tarbiat Modares University protocols, which seek to optimize handling and minimize animal stress (Matani Bour et al., 2018; Roohani et al., 2019; Safavi et al., 2019; Tazikeh et al., 2020).

\section{Funding Information}

The authors wish to thank the Islamic Azad University for financial support.

\section{Author Contribution}

MR: student, lab works, research, drafted version, SB: Main supervisor, design, review, SRJ: drafted version, validation, statistical analysis, $\mathrm{MB}$ : drafted version, validation, statistical analysis

\section{Conflict of Interest}

There is no conflict of interest to report.

\section{Acknowledgements}

The authors wish to thank the Islamic Azad University for financial support. Many thanks to Moha Esmaeili for supporting us in the writing process and other steps of this research. Thanks are also extended to all people for their valuable practical assistance.

\section{References}

Abdel-Tawwab, M., Samir, F., Abd El-Naby, A. S., \& Monier, M. N. (2018). Antioxidative and immunostimulatory effect of dietary cinnamon nanoparticles on the performance of Nile tilapia, Oreochromis niloticus (L.) and its susceptibility to hypoxia stress and Aeromonas hydrophila infection. Fish \& Shellfish Immunology, 74, 19-25. https://doi.org/10.1016/j.fsi.2017.12.033

Abo Ghanima, M. M., Elsadek, M. F., Taha, A. E., El-Hack, A., Mohamed, E., Alagawany, M., Ahmed, B. M., Elshafie, M. M., \& El-Sabrout, K. (2020). Effect of housing system and rosemary and cinnamon essential oils on layers performance, egg quality, haematological traits, blood chemistry, immunity, and antioxidant. Animals, 10(2), 
245. https://doi.org/10.3390/ani10020245

Adel, M., Dawood, M. A., Shafiei, S., Sakhaie, F., \& Shekarabi, S. P. H. (2020). Dietary Polygonum minus extract ameliorated the growth performance, humoral immune parameters, immune-related gene expression and resistance against Yersinia ruckeri in rainbow trout (Oncorhynchus mykiss). Aquaculture, 519, 734738. https://doi.org/10.1016/j.aquaculture.2019.734738

Ahmad, M. H., El Mesallamy, A. M., Samir, F., \& Zahran, F. (2011). Effect of cinnamon (Cinnamomum zeylanicum) on growth performance, feed utilization, whole-body composition, and resistance to Aeromonas hydrophila in nile tilapia. Journal of Applied Aquaculture, 23(4), 289298. https://doi.org/10.1080/10454438.2011.626350

Aksnes, A., \& Opstvedt, J. (1998). Content of digestible energy in fish feed ingredients determined by the ingredientsubstitution method. Aquaculture, 161, 45-53. https://doi.org/10.1016/S0044-8486(97)00255-X

Alsoodeeri, F. N., Alqabbani, H. M., \& Aldossari, N. M. (2020). Effects of Cinnamon (Cinnamomum cassia) Consumption on Serum Lipid Profiles in Albino Rats. Journal of Lipids, 2020. https://doi.org/10.1155/2020/8469830

AOAC. (2000). Official methods of analysis of the AOAC International (Vol. 18).

Asadi, M., Abedian Kenari, A., \& Esmaeili, M. (2020). Restricted- protein feeding strategy decreased the protein consumption without impairing growth performance, flesh quality and non-specific immune parameters in rainbow trout (Oncorhynchus mykiss). Aquaculture, 531, 735946. https://doi.org/10.1016/j.aquaculture.2020.735946

Asgari, M., Abedian Kenari, A., Esmaeili, M., \& Rombenso, A. (2020). Effects of hydroalcoholic extract of honeybee pollen on growth performance, flesh quality, and immune and stress response response of rainbow trout (Oncorhynchus mykiss). Aquaculture Nutrition, 26(5), 1505-1519. https://doi.org/10.1111/anu.13098

Austreng, E., Risa, S., Edwards, D., \& Hvidsten, H. (1977). Carbohydrate in rainbow trout diets. II. Influence of carbohydrate levels on chemical composition and feed utilization of fish from different families. Aquaculture, 11(1), 39-50. https://doi.org/10.1016/00448486(77)90152-1

Baker, W. L., Gutierrez-Williams, G., White, C. M., Kluger, J., \& Coleman, C. I. (2008). Effect of cinnamon on glucose control and lipid parameters. Diabetes care, 31(1), 4143. https://doi.org/10.2337/dc07-1711

Bastos, M. S., Del Vesco, A. P., Santana, T. P., Santos, T. S., de Oliveira Junior, G. M., Fernandes, R. P. M., Barbosa, L. T., \& Gasparino, E. (2017). The role of cinnamon as a modulator of the expression of genes related to antioxidant activity and lipid metabolism of laying quails. PloS One, 12(12), e0189619.

https://doi.org/10.1371/journal.pone.0189619

Bennick, A. (2002). Interaction of plant polyphenols with salivary proteins. Critical Reviews in Oral Biology \& Medicine, 13(2), 184-196.

https://doi.org/10.1177/154411130201300208

Bernfeld, P. (1955). Amylases, $\alpha$ and $\beta$. S.P. Colowick, N.O. Kaplan (Eds.), Methods in Enzymology, vol.1, Academic Press, New York, NY, pp. 149-158. https://doi.org/10.1016/0076-6879(55)01021-5

Bilen, S., Altief, T. A. S., Özdemir, K. Y., Salem, M. O. A., Terzi, E., \& Güney, K. (2020). Effect of lemon balm (Melissa officinalis) extract on growth performance, digestive and antioxidant enzyme activities, and immune responses in rainbow trout (Oncorhynchus mykiss). Fish Physiology and Biochemistry, 46(1), 471-481.

https://doi.org/10.1007/s10695-019-00737-z

Bradford, M. M. (1976). A rapid and sensitive method for the quantitation of microgram quantities of protein utilizing the principle of protein-dye binding. Analytical Biochemistry, 72(1), 248-254. https://doi.org/10.1016/0003-2697(76)90527-3

Brauge, C., Medale, F., \& Corraze, G. (1994). Effect of dietary carbohydrate levels on growth, body composition and glycaemia in rainbow trout, Oncorhynchus mykiss, reared in seawater. Aquaculture, 123(1-2), 109-120. https://doi.org/10.1016/0044-8486(94)90123-6

Citarasu, T. (2010). Herbal biomedicines: a new opportunity for aquaculture industry. Aquaculture International, 18(3), 403-414. https://doi.org/10.1007/s10499-0099253-7

Cottrell, J. J., Furness, J. B., Wijesiriwardana, U. A., Ringuet, M., Liu, F., DiGiacomo, K., Leury, B. J., Clarke, I. J., \& Dunshea, F. R. (2020). The Effect of Heat Stress on Respiratory Alkalosis and Insulin Sensitivity in Cinnamon Supplemented Pigs. Animals, 10(4), 690. https://doi.org/10.3390/ani10040690

Cuvier-Péres, A., Jourdan, S., Fontaine, P., \& Kestemont, P. (2001). Effects of light intensity on animal husbandry and digestive enzyme activities in sea bass Dicentrachus labrax post-larvae. Aquaculture, 202(3-4), 317-328. https://doi.org/10.1016/S0044-8486(01)00781-5

El-Hack, A., Mohamed, E., Alagawany, M., Abdel-Moneim, A.M. E., Mohammed, N. G., Khafaga, A. F., Bin-Jumah, M., Othman, S. I., Allam, A. A., \& Elnesr, S. S. (2020). Cinnamon (Cinnamomum zeylanicum) Oil as a Potential Alternative to Antibiotics in Poultry. Antibiotics, 9(5), 210. https://doi.org/10.3390/antibiotics9050210

Elumalai, P., Kurian, A., Lakshmi, S., Faggio, C., Esteban, M. A., \& Ring $\varnothing$, E. (2020). Herbal immunomodulators in aquaculture. Reviews in Fisheries Science \& Aquaculture, 1-25. https://doi.org/10.1080/23308249.2020.1779651

Esmaeili, M., Abedian Kenari, A., \& Rombenso, A. (2017). Effects of fish meal replacement with meat and bone meal using garlic (Allium sativum) powder on growth, feeding, digestive enzymes and apparent digestibility of nutrients and fatty acids in juvenile rainbow trout (Oncorhynchus mykiss Walbaum, 1792). Aquaculture Nutrition, 23(6), 1225-1234. https://doi.org/10.1111/anu.12491

Esmaeili, M., Abedian Kenari, A., \& Rombenso, A. (2017). Immunohematological status under acute ammonia stress of juvenile rainbow trout (Oncorhynchus mykiss Walbaum, 1792) fed garlic (Allium sativum) powdersupplemented meat and bone meal-based feeds. Comparative Clinical Pathology, 26(4), 853-866. https://doi.org/10.1007/s00580-017-2457-8

FAO. (2020). FAO. 2020. The State of World Fisheries and Aquaculture 2020, Sustainability in action. Food and Agriculture Organization of the United Nations, Rome. https://doi.org/10.4060/ca9229en

Fazio, F. (2019). Fish hematology analysis as an important tool of aquaculture: a review. Aquaculture, 500, 237-242. https://doi.org/10.1016/j.aquaculture.2018.10.030

Ghosi Mobaraki, M. R., Abedian Kenari, A., Bahrami Gorji, S., \& Esmaeili, M. (2020). Effect of dietary fish and vegetable oil on the growth performance, body composition, fatty acids profile, reproductive performance and larval 
resistance in pearl gourami (Trichogaster leeri). Aquaculture Nutrition, 26(3), 894-907.

https://doi.org/10.1111/anu.13048

Goel, B., \& Mishra, S. (2020). Medicinal and Nutritional Perspective of Cinnamon: A Mini-review. European Journal of Medicinal Plants, 31(3), 10-16. https://doi.org/10.9734/ejmp/2020/v31i330218

He, Z.-D., Qiao, C.-F., Han, Q.-B., Cheng, C.-L., Xu, H.-X., Jiang, R.-W., But, P. P.-H., \& Shaw, P.-C. (2005). Authentication and quantitative analysis on the chemical profile of cassia bark (Cortex cinnamomi) by high-pressure liquid chromatography. Journal of Agricultural and Food Chemistry, 53(7), 2424-2428. https://doi.org/10.1021/jf048116s

Hidalgo, M., Urea, E., \& Sanz, A. (1999). Comparative study of digestive enzymes in fish with different nutritional habits. Proteolytic and amylase activities. Aquaculture, 170(3-4), 267-283. https://doi.org/10.1016/S00448486(98)00413-X

Higaki, H., Onji, M., Takeji, S., Uehara, T., Kawasaki, K., Kashimoto, Y., Murakami, T., Yamaguchi, T., Miyaike, J., \& Oomoto, M. (2018). A case of severe drug-induced liver injury caused by over the counter herb (cinnamon): review of literature. Euroasian journal of Hepatogastroenterology, 8(2), 167-171.

https://doi.org/10.5005/jp-journals-10018-1284

Hoseinifar, S. H., Shakouri, M., Van Doan, H., Shafiei, S., Yousefi, M., Raeisi, M., Yousefi, S., Harikrishnan, R., \& Reverter, M. (2020). Dietary supplementation of lemon verbena (Aloysia citrodora) improved immunity, immune-related genes expression and antioxidant enzymes in rainbow trout (Oncorrhyncus mykiss). Fish \& Shellfish Immunology, 99, 379-385.

https://doi.org/10.1016/j.fsi.2020.02.006

Hosseinpour Aghaei, R., Abedian Kenari, A., Yazdani Sadati, M. A., \& Esmaeili, M. (2018). The effect of time-dependent protein restriction on growth factors, nonspecific immunity, body composition, fatty acids and amino acids in the Siberian sturgeon (Acipenser baerii). Aquaculture Research, 49(9), 3033-3044.

https://doi.org/10.1111/are.13764

Hou, Z.-S., Wen, H.-S., Li, J.-F., He, F., Li, Y., Qi, X., Zhao, J., Zhang, K.-Q., \& Tao, Y.-X. (2019). Effects of photoperiod and light Spectrum on growth performance, digestive enzymes, hepatic biochemistry and peripheral hormones in spotted sea bass (Lateolabrax maculatus). Aquaculture, 507, 419-427.

https://doi.org/10.1016/j.aquaculture.2019.04.029

lijima, N., Tanaka, S., \& Ota, Y. (1998). Purification and characterization of bile salt-activated lipase from the hepatopancreas of red sea bream, Pagrus major. Fish Physiology and Biochemistry, 18(1), 59-69. https://doi.org/10.1023/A:1007725513389

Innes, J. K., \& Calder, P. C. (2020). Marine omega-3 (n-3) fatty acids for cardiovascular health: an update for 2020. International Journal of Molecular Sciences, 21(4), 1362. https://doi.org/10.3390/ijms21041362

Karataş, T., Korkmaz, F., Karataş, A., \& Yildirim, S. (2020). Effects of Rosemary (Rosmarinus officinalis) extract on growth, blood biochemistry, immunity, antioxidant, digestive enzymes and liver histopathology of rainbow trout, Oncorhynchus mykiss. Aquaculture Nutrition. https://doi.org/10.1111/anu.13100

Kenari, A. A., Mahmoudi, N., Soltani, M., \& Abediankenari, S. (2013). Dietary nucleotide supplements influence the growth, haemato-immunological parameters and stress responses in endangered Caspian brown trout (Salmo trutta caspius Kessler, 1877). Aquaculture Nutrition, 19(1), 54-63.

https://doi.org/10.1111/j.1365-2095.2012.00938.x

Khan, A., Safdar, M., Khan, M. M. A., Khattak, K. N., \& Anderson, R. A. (2003). Cinnamon improves glucose and lipids of people with type 2 diabetes. Diabetes Care, 26(12), 3215-3218.

https://doi.org/10.2337/diacare.26.12.3215

Lee, E.-J., Kim, J.-R., Choi, D.-R., \& Ahn, Y.-J. (2008). Toxicity of cassia and cinnamon oil compounds and cinnamaldehyde-related compounds to Sitophilus oryzae (Coleoptera: Curculionidae). Journal of Economic Entomology, 101(6), 1960-1966.

https://doi.org/10.1603/0022-0493-101.6.1960

Lemieux, H., Blier, P., \& Dutil, J.-D. (1999). Do digestive enzymes set a physiological limit on growth rate and food conversion efficiency in the Atlantic cod (Gadus morhua)? Fish Physiology and Biochemistry, 20(4), 293303. https://doi.org/10.1023/A:1007791019523

Lungarini, S., Aureli, F., \& Coni, E. (2008). Coumarin and cinnamaldehyde in cinnamon marketed in Italy: a natural chemical hazard? Food Additives and Contaminants, 25(11), 1297-1305. https://doi.org/10.1080/02652030802105274

Maierean, S. M., Serban, M.-C., Sahebkar, A., Ursoniu, S., Serban, A., Penson, P., Banach, M., Lipid, \& Collaboration, B. P. M.-a. (2017). The effects of cinnamon supplementation on blood lipid concentrations: a systematic review and meta-analysis. Journal of Clinical Lipidology, 11(6), 1393-1406. https://doi.org/10.1016/j.jacl.2017.08.004

Martínez-Álvarez, R. M., Morales, A. E., \& Sanz, A. (2005). Antioxidant defenses in fish: biotic and abiotic factors. Reviews in Fish Biology and Fisheries, 15(1-2), 75-88. https://doi.org/10.1007/s11160-005-7846-4

Matani Bour, H., Esmaeili, M., \& Abedian Kenari, A. (2018). Growth performance, muscle and liver composition, blood traits, digestibility and gut bacteria of beluga (Huso huso) juvenile fed different levels of soybean meal and lactic acid. Aquaculture Nutrition, 24(4), 1361-1368. https://doi.org/10.1111/anu.12673

Mehdipour, Z., Afsharmanesh, M., \& Sami, M. (2013). Effects of dietary synbiotic and cinnamon (Cinnamomum verum) supplementation on growth performance and meat quality in Japanese quail. Livestock Science, 154(1-3), 152-157. https://doi.org/10.1016/j.livsci.2013.03.014

Mollazadeh, H., \& Hosseinzadeh, H. (2016). Cinnamon effects on metabolic syndrome: a review based on its mechanisms. Iranian Journal of Basic Medical Sciences, 19(12), 1258-1270. https://dx.doi.org/10.22038\%2Fijbms.2016.7906

Montazeri Parchikolaei, H., Abedian Kenari, A., \& Esmaeili, M. (2021). Soybean-based diets plus probiotics improve the profile of fatty acids, digestibility, intestinal microflora, growth performance, and the innate immunity of beluga (Huso huso). Aquaculture Research. 52(1), 152-166. https://doi.org/10.1111/are.14877

Nakhjavani, M., Rajab, A., Rabizadeh, S., Bitaraf, M., Ghanei, A., Esteghamati, A., \& Mirmiranpour, H. (2020). Lecithincholesterol acyltransferase (LCAT) activity is lower in patients with type 2 diabetes in the presence of metabolic syndrome. Bioactive Compounds in Health and Disease, 3(4), 66-73. 
https://doi.org/10.31989/bchd.v3i4.690

NRC. (2011). National Research Council, Nutrient requirements of fish and shrimp, The National Academies Press, Washington DC. National academies press.

Ogawa, K., Honda, M., Tanigawa, A., Hatase, A., Ito, A., Higa, Y., \& Morinaga, O. (2020). Appetite-enhancing effects of inhaling cinnamon, clove, and fennel essential oils containing phenylpropanoid analogues. Journal of Natural Medicines, 1-12. https://doi.org/10.1007/s11418-020-01423-8

Pandey, D. K., Chaudhary, R., Dey, A., Nandy, S., Banik, R., Malik, T., \& Dwivedi, P. (2020). Current Knowledge of Cinnamomum Species: A Review on the Bioactive Components, Pharmacological Properties, Analytical and Biotechnological Studies. In Bioactive Natural products in Drug Discovery (pp. 127-164). Springer. https://doi.org/10.1007/978-981-15-1394-7_3

Platel, K., \& Srinivasan, K. (2004). Digestive stimulant action of spices: a myth or reality? The Indian Journal of Medical Research, 119(5), 167-179.

Rahman, S., Begum, H., Rahman, Z., Ara, F., Iqbal, M. J., \& Yousuf, A. K. M. (2013). Effect of cinnamon (Cinnamomum cassia) as a lipid lowering agent on hypercholesterolemic rats. Journal of Enam Medical College, 3(2), 94-98.

https://doi.org/10.3329/jemc.v3i2.16132

Ramezanzadeh, S., Abedian Kenari, A., \& Esmaeili, M. (2020). Immunohematological parameters of rainbow trout (Oncorhynchus mykiss) fed supplemented diet with different forms of barberry root (Berberis vulgaris). Comparative Clinical Pathology, 29, 177-187. https://doi.org/10.1007/s00580-019-03032-8

Ramezanzadeh, S., Abedian Kenari, A., Esmaeili, M., \& Rombenso, A. (2020). Effects of different forms of barberry root (Berberis vulgaris) on growth performance, muscle fatty acids profile, whole-body composition, and digestive enzymes of rainbow trout (Oncorhynchus mykiss). Journal of the World Aquaculture Society. In press. https://doi.org/10.1111/jwas.12722

Rao, P. V., \& Gan, S. H. (2014). Cinnamon: a multifaceted medicinal plant. Evidence-Based Complementary and Alternative Medicine, 2014. https://doi.org/10.1155/2014/642942

Řehulka, J., Minařík, B., \& Řehulková, E. (2004). Red blood cell indices of rainbow trout Oncorhynchus mykiss (Walbaum) in aquaculture. Aquaculture Research, 35(6), 529-546. https://doi.org/10.1111/j.1365-2109.2004.01035.x

Roohani, A. M., Abedian Kenari, A., Fallahi Kapoorchali, M., Borani, M. S., Zoriezahra, S. J., Smiley, A. H., Esmaeili, M., \& Rombenso, A. N. (2019). Effect of spirulina Spirulina platensis as a complementary ingredient to reduce dietary fish meal on the growth performance, wholebody composition, fatty acid and amino acid profiles, and pigmentation of Caspian brown trout (Salmo trutta caspius) juveniles. Aquaculture Nutrition, 25(3), 633-645. https://doi.org/10.1111/anu.12885

Saeed, M., Kamboh, A., Syed, S., Babazadeh, D., Suheryani, I., Shah, Q., Umar, M., Kakar, I., Naveed, M., \& Abd El-Hack, M. (2018). Phytochemistry and beneficial impacts of cinnamon (Cinnamomum zeylanicum) as a dietary supplement in poultry diets. World's Poultry Science Journal, 74(2), 331-346. https://doi.org/10.1017/\$0043933918000235

Safavi, S. V., Abedian Kenari, A., Tabarsa, M., \& Esmaeili, M. (2019). Effect of sulfated polysaccharides extracted from marine macroalgae (Ulva intestinalis and Gracilariopsis persica) on growth performance, fatty acid profile, and immune response of rainbow trout (Oncorhynchus mykiss). Journal of Applied Phycology, 31, 4021-4035. https://doi.org/10.1007/s10811-019-01902-w

Sankar, H., Philip, B., Philip, R., \& Singh, I. (2017). Effect of probiotics on digestive enzyme activities and growth of cichlids, Etroplus suratensis (Pearl spot) and Oreochromis mossambicus (Tilapia). Aquaculture Nutrition, 23(4), 852-864.

https://doi.org/10.1111/anu.12452

Santos, H. O., \& da Silva, G. A. (2018). To what extent does cinnamon administration improve the glycemic and lipid profiles? Clinical Nutrition ESPEN, 27, 1-9. https://doi.org/10.1016/j.clnesp.2018.07.011

Sen, S., \& Chakraborty, R. (2011). The role of antioxidants in human health. In Oxidative stress: diagnostics, prevention, and therapy (pp. 1-37). ACS Publications. https://doi.org/10.1021/bk-2011-1083.ch001

Shearer, K. D. (1994). Factors affecting the proximate composition of cultured fishes with emphasis on salmonids. Aquaculture, 119(1), 63-88. https://doi.org/10.1016/0044-8486(94)90444-8

Sierra-Puente, D., Abadi-Alfie, S., Arakanchi-Altaled, K., Bogard-Brondo, M., García-Lascurain, M., \& GutiérrezSalmeán, G. (2020). Cinammon (Cinnamomum Spp.) and Type 2 Diabetes Mellitus. Current Topics In Nutraceutical Research, 18(3), 247-255. https://doi.org/10.37290/ctnr2641-452X.18:247-255

Singh, J., Sethi, A., Sikka, S., Chatli, M., \& Kumar, P. (2014). Effect of cinnamon (Cinnamomum cassia) powder as a phytobiotic growth promoter in commercial broiler chickens. Animal Nutrition and Feed Technology, 14(3), 471-479. https://doi.org/10.5958/0974-181X.2014.01349.3

Tazikeh, T., Abedian Kenari, A., \& Esmaeili, M. (2020). Effects of fish meal replacement by meat and bone meal supplemented with garlic (Allium sativum) powder on biological indices, feeding, muscle composition, fatty acid and amino acid profiles of whiteleg shrimp (Litopenaeus vannamei). Aquaculture Research, 51(2), 674-686. https://doi.org/10.1111/are.14416

Toghyani, M., Toghyani, M., Gheisari, A., Ghalamkari, G., \& Eghbalsaied, S. (2011). Evaluation of cinnamon and garlic as antibiotic growth promoter substitutions on performance, immune responses, serum biochemical and haematological parameters in broiler chicks. Livestock Science, 138(1-3), 167-173. https://doi.org/10.1016/j.livsci.2010.12.018

Van Wyk, B.-E., \& Wink, M. (2018). Medicinal plants of the world. CABI. https://doi.org/10.1079/9781786393258.0000

Wang, Y. W., Zhu, J., Ge, X. p., Sun, S. M., Su, Y. L., Li, B., Hou, Y. R., \& Ren, M. C. (2019). Effects of stocking density on the growth performance, digestive enzyme activities, antioxidant resistance, and intestinal microflora of blunt snout bream (Megalobrama amblycephala) juveniles. Aquaculture Research, 50(1), 236-246. https://doi.org/10.1111/are.13889

Zargar, A., Taheri Mirghaed, A., Mirzargar, S. S., Ghelichpour, M., Yousefi, M., \& Hoseini, S. M. (2020). Dietary ginger administration attenuates oxidative stress and 
immunosuppression caused by oxytetracycline in rainbow trout (Oncorhynchus mykiss). Aquaculture Research. In press. https://doi.org/10.1111/are.14763

Zeilab Sendijani, R., Abedian Kenari, A., Smiley, A. H., \& Esmaeili, M. (2020). The effect of extract from dill (Anethum graveolens) on the growth performance, body composition, immune system and antioxidant system of Rainbow Trout (Oncorhynchus mykiss). North American Journal of Aquaculture, 82(2), 119-131. https://doi.org/10.1002/naaq.10123

Zhang, Y., Wei, Z., Liu, G., Deng, K., Yang, M., Pan, M., Gu, Z., Liu, D., Zhang, W., \& Mai, K. (2019). Synergistic effects of dietary carbohydrate and taurine on growth performance, digestive enzyme activities and glucose metabolism in juvenile turbot Scophthalmus maximus L. Aquaculture, 499, 32-41. https://doi.org/10.1016/j.aquaculture.2018.08.082

Zhou, Y., Jiang, W.-D., Zhang, J.-X., Feng, L., Wu, P., Liu, Y., Jiang, J., Kuang, S.-Y., Tang, L., \& Peng, Y. (2020). Cinnamaldehyde improves the growth performance and digestion and absorption capacity in grass carp (Ctenopharyngodon idella). Fish Physiology and Biochemistry. In press https://doi.org/10.1007/s10695020-00813-9 